\title{
Neptunomonas antarctica sp. nov., isolated from marine sediment
}

\author{
Xi-Ying Zhang, ${ }^{1}{ }^{\dagger}$ Yan-Jiao Zhang, ${ }^{1} \dagger$ Yong $Y u,{ }^{2}$ Hui-Juan $L i,{ }^{1,3}$ \\ Zhao-Ming Gao, ${ }^{1}$ Xiu-Lan Chen, ${ }^{1}$ Bo Chen $^{2}$ and Yu-Zhong Zhang ${ }^{1}$ \\ ${ }^{1}$ The State Key Laboratory of Microbial Technology, Marine Biotechnology Research Center, \\ Shandong University, Jinan 250100, PR China \\ ${ }^{2}$ SOA Key Laboratory for Polar Science, Polar Research Institute of China, Shanghai 200136, PR \\ China \\ ${ }^{3}$ College of Chemical and Environmental Engineering, Shandong University of Science and \\ Technology, Qingdao 266510, PR China
}

\author{
Correspondence \\ Yu-Zhong Zhang \\ zhangyz@sdu.edu.cn \\ Bo Chen \\ chenbo@pric.gov.cn
}

The genus Neptunomonas was originally proposed by Hedlund et al. (1999) and currently contains two species: Neptunomonas naphthovorans (Hedlund et al., 1999) and Neptunomonas japonica (Miyazaki et al., 2008). The type strain of $N$. naphthovorans, a polycyclic aromatic hydrocarbon-degrading bacterium, was isolated from creosotecontaminated harbour sediment (Hedlund et al., 1999), while that of $N$. japonica was isolated from marine sediment adjacent to a sperm whale carcass (Miyazaki et al., 2008).

A Neptunomonas-like bacterial strain, designated $\mathrm{S} 3-22^{\mathrm{T}}$, was isolated during a study to screen cold-adapted microorganisms from Antarctic marine sediment. Samples were collected from the Nella Fjord, Antarctica (69 $22^{\prime} 06^{\prime \prime} \mathrm{S} 76^{\circ}$ $22^{\prime} 45^{\prime \prime}$ E) at a water depth of $20 \mathrm{~m}$ during the 23rd

†These authors contributed equally to this work.

The GenBank/EMBL/DDBJ accession number for the 16S rRNA gene sequence of strain S3-22 ${ }^{\top}$ is FJ713802.

A maximum-parsimony phylogenetic tree based on $16 \mathrm{~S}$ rRNA gene sequences and a transmission electron micrograph of a negatively stained cell of strain $\mathrm{S} 3-22^{\top}$ are available as supplementary material with the online version of this paper.
Chinese National Antarctic Research Expedition on 12 January 2007, stored in sterilized plastic bags $(250 \mathrm{ml})$ and transported to the laboratory at $4{ }^{\circ} \mathrm{C}$. For isolation of bacterial strains, approximately $1 \mathrm{~g}$ wet sediment was mixed with $99 \mathrm{ml}$ sterilized natural Antarctic seawater supplemented with 10 glass beads (diameter $2-3 \mathrm{~mm}$ ) and shaken at $4{ }^{\circ} \mathrm{C}$ and 300 r.p.m. for 1 h. The suspension was serially diluted (to $10^{-6}$ ) with sterilized seawater and $100 \mu \mathrm{l}$ aliquots of each dilution were spread onto marine agar 2216 (MA; Difco) plates. After incubation at $4{ }^{\circ} \mathrm{C}$ for 4 weeks, individual colonies were picked and purified by subcultivation on MA. Strain $\mathrm{S} 3-22^{\mathrm{T}}$ was routinely cultivated at $15{ }^{\circ} \mathrm{C}$ in TYS broth $[0.5 \%$ tryptone (Oxoid), $0.1 \%$ yeast extract (Oxoid), artificial seawater (containing $2.75 \% \mathrm{NaCl}, 0.07 \% \mathrm{KCl}, 0.54 \% \mathrm{MgCl}_{2} .6 \mathrm{H}_{2} \mathrm{O}, 0.68 \%$ $\mathrm{MgSO}_{4} \cdot 7 \mathrm{H}_{2} \mathrm{O}, 0.14 \% \mathrm{CaCl}_{2} \cdot 2 \mathrm{H}_{2} \mathrm{O}, 0.02 \% \mathrm{NaHCO}_{3}$ and distilled water; Miyazaki et al., 2008)] or on TYS agar $\left(1.5 \%\right.$ agar) and was stored at $-80{ }^{\circ} \mathrm{C}$ in TYS broth with $20 \%$ (v/v) glycerol. N. japonica JCM $14595^{\mathrm{T}}$ was obtained from the Japan Collection of Microorganisms.

Genomic DNA of strain $\mathrm{S} 3-22^{\mathrm{T}}$ was obtained using a bacterial genomic DNA isolation kit (BioTeke). The 16S rRNA gene of strain $S 3-22^{\mathrm{T}}$ was amplified from the 
genomic DNA by PCR with the universal primers 27F $\left(5^{\prime}\right.$-AGAGTTTGATCCTGGCTCAG-3') and 1492R (5'ACGGCTACCTTGTTACGACTT-3') (Lane, 1991) and sequenced by Biosune using an automated DNA sequencer (model 3730; Applied Biosystems). The 16S rRNA gene sequence obtained was aligned manually with those of related taxa retrieved from GenBank using MEGA version 4.0 (Tamura et al., 2007). Phylogenetic trees were generated in MEGA using the neighbour-joining (Saitou \& Nei, 1987) and maximum-parsimony (Fitch, 1971) methods. The topologies of the phylogenetic trees obtained were evaluated using bootstrap analyses with 1000 replications. Evolutionary distances for the neighbour-joining method were calculated using the model of Jukes \& Cantor (1969). The DNA G $+\mathrm{C}$ content of strain $\mathrm{S} 3-22^{\mathrm{T}}$ was determined by HPLC (Mesbah et al., 1989). DNA-DNA hybridization experiments between strain $\mathrm{S} 3-22^{\mathrm{T}}$ and $N$. japonica JCM $14595^{\mathrm{T}}$ were conducted at the DSMZ using the methods of De Ley et al. (1970) modified by Huß et al. (1983).

Cellular morphology was observed by transmission electron microscopy (JEM-100CXII; JEOL) using cells grown in TYS broth for 2 days and negatively stained with $2.5 \%$ (w/v) phosphotungstic acid. Colony morphology was observed after incubation on TYS agar at $15{ }^{\circ} \mathrm{C}$ for 10 14 days. The Gram reaction was examined following the standard Gram procedure (Murray et al., 1994). Growth at $\mathrm{pH}$ 5.0-9.0 (in increments of $0.5 \mathrm{pH}$ units) was tested at $15{ }^{\circ} \mathrm{C}$ in TYS broth with the $\mathrm{pH}$ adjusted with MES (pH 5.0-6.0, $50 \mathrm{mM}$ ), MOPS (pH 6.5-7.0, $50 \mathrm{mM}$ ), Tris (pH 7.5-8.5, $50 \mathrm{mM}$ ) or CHES (pH 9.0, $50 \mathrm{mM})$. Growth at $4,10,15,20,25,26,27,28$ and $30{ }^{\circ} \mathrm{C}$ was determined in TYS broth at $\mathrm{pH}$ 7.0. Growth with $0,0.5,1,2,3,4,5,6,7$ and $8 \%(\mathrm{w} / \mathrm{v}) \mathrm{NaCl}$ was examined in broth containing $0.5 \%$ tryptone, $0.1 \%$ yeast extract, $0.5 \% \mathrm{MgCl}_{2}, 0.2 \%$ $\mathrm{MgSO}_{4}, 0.05 \% \mathrm{CaCl}_{2}, 0.1 \% \mathrm{KCl}, 0.0001 \% \mathrm{FeSO}_{4}$ and distilled water ( $\mathrm{pH}$ 7.0). Acid production from carbohydrates, including D-glucose, D-fructose, D-mannitol, maltose, D-xylose, D-galactose, sucrose and lactose, was tested at $15{ }^{\circ} \mathrm{C}$ using modified $\mathrm{O} / \mathrm{F}$ medium $[0.1 \%$ Casitone (Difco), $0.01 \%$ yeast extract, $0.05 \%\left(\mathrm{NH}_{4}\right)_{2} \mathrm{SO}_{4}, 0.05 \%$ Tris, $0.001 \%$ phenol red, $1 \%$ carbohydrate, $0.3 \%$ agar and half-strength artificial seawater; Leifson, 1963]. Hydrolysis of starch and casein was tested on TYS agar supplemented with $1 \%(\mathrm{w} / \mathrm{v})$ soluble starch or $0.3 \%(\mathrm{w} / \mathrm{v})$ casein. Catalase activity was detected by bubble production in $3 \%$ (v/v) $\mathrm{H}_{2} \mathrm{O}_{2}$ solution. Oxidase activity was determined by using commercial oxidase test strips (Tianhe Microorganism Reagent Co.). DNase activity was detected by using DNase test agar (Tianhe Microorganism Reagent Co.) prepared using artificial seawater. Tests for other enzyme activities, nitrate reduction, aesculin hydrolysis and production of $\mathrm{H}_{2} \mathrm{~S}$, indole and acetoin were performed using API ZYM, API 20E and API 20NE strips (bioMérieux) according to the manufacturer's instructions except that cells were suspended in artificial seawater. Anaerobic growth was tested in marine broth 2216 (Difco) using an anaerobic chamber (Forma 1029; Thermo Electron).

After growth in TYS broth at $15{ }^{\circ} \mathrm{C}$ for $48 \mathrm{~h}$, cellular fatty acid analysis of cells of strain $\mathrm{S} 3-22^{\mathrm{T}}$ and $N$. japonica JCM $14595^{\mathrm{T}}$ was performed at the Institute of Microbiology and Epidemiology, Academy of Military Medical Sciences, Beijing, PR China, according to the instructions of the Sherlock Microbial Identification System. Analysis of respiratory quinones was carried out by Dr Brian Tindall of the DSMZ using the methods described by Tindall (1990a, b).

A nearly full-length $16 \mathrm{~S}$ rRNA gene sequence of strain S3$22^{\mathrm{T}}$ (1508 nt) was obtained. Comparison of $16 \mathrm{~S}$ rRNA gene sequences revealed that strain $\mathrm{S} 3-22^{\mathrm{T}}$ had highest sequence similarity to the type strains of the two known Neptunomonas species ( $97.1 \%$ to N. japonica JAMM $0745^{\mathrm{T}}$ and $94.8 \%$ to $N$. naphthovorans NAG-2N-126 ${ }^{\mathrm{T}}$ ) and less than $94 \%$ sequence similarity to strains from other closely related genera. In the neighbour-joining tree, strain $\mathrm{S} 3-22^{\mathrm{T}}$ was grouped within the phylogenetic branch of the genus Neptunomonas with high bootstrap support (98\%; Fig. 1). The maximum-parsimony tree showed a very similar topology (Supplementary Fig. S1, available in IJSEM Online). DNA-DNA relatedness between strain $\mathrm{S} 3-22^{\mathrm{T}}$ and N. japonica JCM $14595^{\mathrm{T}}$ was $20.4 \%$. This value is far below the threshold value of $70 \%$ recommended for the delineation of bacterial species (Wayne et al., 1987;

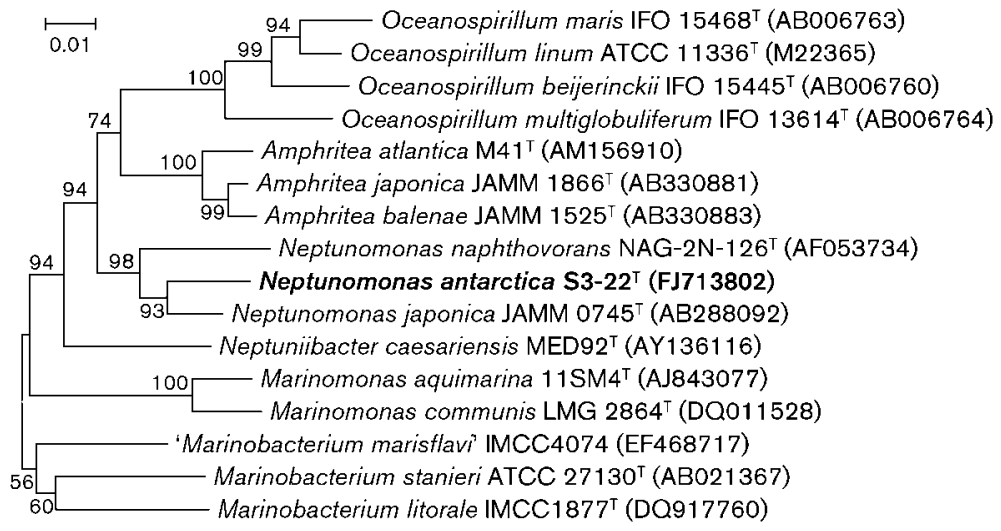

Fig. 1. Neighbour-joining phylogenetic tree based on 16S rRNA gene sequences showing the phylogenetic positions of strain S3-22 $2^{\top}$ and representatives of genus Neptunomonas and some other related genera. Bootstrap values $(>50 \%)$ based on 1000 replications are shown at branch nodes. Bar, 0.01 substitutions per nucleotide position. 
Stackebrandt \& Goebel, 1994). Thus, the phylogenetic analysis and DNA-DNA hybridization experiments suggested that strain $\mathrm{S} 3-22^{\mathrm{T}}$ belongs to the genus Neptunomonas and represents a novel species in this genus.

The DNA G $+\mathrm{C}$ content of strain $\mathrm{S} 3-22^{\mathrm{T}}$ was $45.6 \mathrm{~mol} \%$, which is an intermediate value between those of $N$. japonica and $N$. naphthovorans (43.6 and $46.3 \mathrm{~mol} \%$, respectively). The fatty acids of strain S3-22 ${ }^{\mathrm{T}}$ were summed feature 3 $\left(\mathrm{C}_{16: 1} \omega 7 c\right.$ and/or iso- $\left.\mathrm{C}_{15: 0} 2-\mathrm{OH} ; 65.6 \%\right), \mathrm{C}_{16: 0}(17.3 \%)$, $\mathrm{C}_{18: 1} \omega 7 c(5.5 \%)$, an unknown fatty acid with equivalent chain-length $11.799(4.3 \%)$ and $\mathrm{C}_{10: 0} 3-\mathrm{OH}(4.3 \%)$, which accounted for $97 \%$ of the total cellular fatty acids, and $\mathrm{C}_{18: 0}(0.8 \%), \mathrm{C}_{10: 0}(0.7 \%), \mathrm{C}_{12: 0}(0.7 \%), \mathrm{C}_{18: 1} \omega 9 c$ $(0.5 \%)$ and $\mathrm{C}_{14: 0}(0.3 \%)$. In comparison with the fatty acid pattern of $N$. japonica JCM $14595^{\mathrm{T}}$, strain $\mathrm{S} 3-22^{\mathrm{T}}$ was similar in that summed feature $3, \mathrm{C}_{16: 0}$ and $\mathrm{C}_{18: 1} \omega 7 c$ were the major fatty acids $(>5 \%)$ and that $\mathrm{C}_{10: 0} 3-\mathrm{OH}$ was the major 3-hydroxy fatty acid, but it was quite different in the proportions of the major fatty acids, especially $\mathrm{C}_{18: 1} \omega 7 c$ (Table 1 ). The only respiratory quinone of strain $\mathrm{S} 3-22^{\mathrm{T}}$ was Q-8, whereas the other two Neptunomonas species possessed minor amounts of Q9 (1\%) in addition to Q-8 (Miyazaki et al., 2008).

The morphological, physiological and biochemical characteristics of strain $\mathrm{S} 3-22^{\mathrm{T}}$ are given in the species description and in Table 2. Cells of strain S3-22 ${ }^{\mathrm{T}}$ were Gram-negative rods, $0.6-1.0 \mu \mathrm{m}$ in diameter and 1.6$1.8 \mu \mathrm{m}$ long, that were motile with single polar flagella (Supplementary Fig. S2). Strain S3-22 ${ }^{\mathrm{T}}$ exhibited some phenotypic features that are common to the other Neptunomonas species, such as facultatively aerobic growth, the presence of oxidase and catalase activities, the absence of amylase activity and the inability to produce $\mathrm{H}_{2} \mathrm{~S}$, which supported the phylogenetic assignment of strain S3-22 ${ }^{\mathrm{T}}$ to the genus Neptunomonas. However, strain $\mathrm{S} 3-22^{\mathrm{T}}$ could be differentiated phenotypically from the other Neptunomonas species by its ability to grow at $\mathrm{pH} 6$. In addition, strain S3-22 $2^{\mathrm{T}}$ differed from $N$. japonica JCM $14595^{\mathrm{T}}$ by its ability to produce acids from some carbohydrates and its inability to produce DNase and gelatinase and differed from $N$. naphthovorans by its ability to reduce nitrate and its inability to produce indole or to grow with $7 \% \mathrm{NaCl}$ (Table 2).

The results from the phylogenetic analysis of $16 \mathrm{~S}$ rRNA gene sequences, DNA-DNA hybridization experiments and chemotaxonomic and phenotypic analyses demonstrate that strain $\mathrm{S} 3-22^{\mathrm{T}}$ represents a novel species of the genus Neptunomonas, for which the name Neptunomonas antarctica sp. nov. is proposed.

\section{Description of Neptunomonas antarctica sp. nov.}

Neptunomonas antarctica (an.tarc'ti.ca. N.L. fem. adj. antarctica from the Antarctic).

Cells are Gram-negative rods $(0.6-1.0 \times 1.6-1.8 \mu \mathrm{m})$, motile with single polar flagella. Colonies are white, small, circular (0.5-1.2 mm diameter), convex and smooth when grown on TYS agar at $15{ }^{\circ} \mathrm{C}$ for 10 days. Facultatively aerobic. Oxidase- and catalase-positive. Growth occurs at $4-25{ }^{\circ} \mathrm{C}$ (optimum $15{ }^{\circ} \mathrm{C}$ ) and $\mathrm{pH}$ 6.0-8.0 (optimum $\mathrm{pH}$ 6.5-7.0). Grows with $0.5-5 \% \mathrm{NaCl}$ (optimum 2-3\%); does not grow without $\mathrm{NaCl}$. Does not hydrolyse casein, aesculin (API $20 \mathrm{NE}$ ) or starch. Negative for DNase activity. Nitrate is reduced to nitrite (API 20NE). Indole, acetoin (VogesProskauer reaction) and $\mathrm{H}_{2} \mathrm{~S}$ are not produced (API 20E). Acids are produced oxidatively from D-fructose and Dmannitol, but not from D-glucose, maltose, D-xylose, Dgalactose, sucrose or lactose. In API 20E tests, arginine dihydrolase, lysine decarboxylase, ornithine decarboxylase, tryptophan deaminase, gelatinase and urease are not detected. In API ZYM tests, alkaline phosphatase, acid phosphatase, leucine arylamidase, esterase (C4) (weak),

Table 1. Fatty acid compositions of strain $\mathrm{S} 3-22^{\top}$ and the type strains of Neptunomonas species

Strains: 1, Neptunomonas antarctica sp. nov. S3-22 $2^{\mathrm{T}}$; 2, N. japonica JCM $14595^{\mathrm{T}}$ (data from this study); 3 , N. naphthovorans ATCC $700637^{\mathrm{T}}$ (Miyazaki et al., 2008). Values are percentages of total fatty acids; fatty acids representing $\leqslant 0.5 \%$ of the total in all strains are not shown. ECL, Equivalent chain-length; -, not detected/not reported.

\begin{tabular}{|c|c|c|c|}
\hline Fatty acid & 1 & 2 & 3 \\
\hline $\mathrm{C}_{10: 0}$ & 0.7 & 1.8 & - \\
\hline $\mathrm{C}_{10: 0} 3-\mathrm{OH}$ & 4.3 & 3.4 & 6.9 \\
\hline $\mathrm{C}_{12: 0}$ & 0.7 & 0.2 & 6.2 \\
\hline $\mathrm{C}_{16: 0}$ & 17.3 & 10.3 & 19.5 \\
\hline $\mathrm{C}_{16: 1}$ & - & - & 37.8 \\
\hline $\mathrm{C}_{18: 1}$ & - & - & 26.5 \\
\hline $\mathrm{C}_{18: 1} \omega 7 c$ & 5.5 & 21.8 & - \\
\hline Unknown ECL 11.799 & 4.3 & 2.1 & - \\
\hline Summed feature $3^{*}$ & 65.6 & 59.6 & - \\
\hline
\end{tabular}

${ }^{*}$ Summed features represent two or three fatty acids that cannot be separated by the Microbial Identification System. Summed feature 3 consisted of $\mathrm{C}_{16: 1} \omega 7 c$ and/or iso- $\mathrm{C}_{15: 0} 2-\mathrm{OH}$. 
Table 2. Differential characteristics of strain $\mathrm{S} 3-22^{\top}$ and the type strains of Neptunomonas species

Strains: 1, N. antarctica sp. nov. S3-22 ${ }^{\mathrm{T}} ; 2$, N. japonica JCM $14595^{\mathrm{T}}$ (data from Miyazaki et al., 2008); 3, N. naphthovorans ATCC $700637^{\mathrm{T}}$ (Hedlund et al., 1999). All strains were rod-shaped, Gram-negative, motile, facultatively aerobic, catalase- and oxidase-positive and amylase-negative and negative for $\mathrm{H}_{2} \mathrm{~S}$ production and contained Q-8 as the major quinone.

\begin{tabular}{|lccc|}
\hline Characteristic & $\mathbf{1}$ & $\mathbf{2}$ & $\mathbf{3}$ \\
\hline Cell dimensions $(\mu \mathrm{m})$ & & & \\
$\quad$ Length & $1.2-1.8$ & $1.6-1.8$ & $2.0-3.0$ \\
Width & $0.6-1.0$ & $0.8-1.0$ & $0.7-0.9$ \\
Flagellum position & $\mathrm{P}$ & $\mathrm{P} / \mathrm{sT}$ & $\mathrm{P}$ \\
Growth with/at: & & & \\
$\quad 7 \% \mathrm{NaCl}$ & - & - & + \\
$\mathrm{pH} 6$ & + & - & - \\
Reduction of nitrate & + & + & - \\
Production of indole & - & - & + \\
Acid production from carbohydrates & + & - & + \\
Enzyme activity & & & \\
$\quad$ Gelatinase & - & + & - \\
$\quad$ DNase & - & + & - \\
DNA G + C content (mol\%) & 45.6 & 43.6 & 46.3 \\
\end{tabular}

${ }^{\star}$ P, Polar; ST, subterminal.

esterase lipase (C8) (weak), valine arylamidase (weak) and trypsin (weak) are detected, but lipase (C14), cystine arylamidase, $\alpha$-chymotrypsin, naphthol-AS-BI-phosphohydrolase, $\alpha$-galactosidase, $\beta$-galactosidase, $\beta$-glucuronidase, $\alpha$-glucosidase, $\beta$-glucosidase, $N$-acetyl- $\beta$-glucosaminidase, $\alpha$-mannosidase and $\alpha$-fucosidase are not detected. The respiratory quinone is $\mathrm{Q}-8$. The major cellular fatty acids $(>5 \%)$ are summed feature $3\left(\mathrm{C}_{16: 1} \omega 7 c\right.$ and/or iso- $\mathrm{C}_{15: 0} 2-$ $\mathrm{OH}), \mathrm{C}_{16: 0}$ and $\mathrm{C}_{18: 1} \omega 7 c$. The DNA $\mathrm{G}+\mathrm{C}$ content of the type strain is $45.6 \mathrm{~mol} \%$.

The type strain is $\mathrm{S} 3-22^{\mathrm{T}}$ (=CCTCC AB $209086^{\mathrm{T}}=\mathrm{KACC}$ $14056^{\mathrm{T}}$ ), isolated from marine sediment of the Nella Fjord, Antarctica.

\section{Acknowledgements}

We thank Dr Boris I. Sirenko from the Zoological Institute of Russian Academy of Sciences for his help in collecting the marine sediment samples. The work was supported financially by the Hi-Tech Research and Development Program of China (2007AA091903, 2007AA021306), the National Natural Science Foundation of China (40706001), the National Basic Research Program of China (2004CB719601), the COMRA Program (DYXM-115-02-2-6) and the Chinese Polar Science Stratagem Fund (200601).

\section{References}

De Ley, J., Cattoir, H. \& Reynaerts, A. (1970). The quantitative measurement of DNA hybridization from renaturation rates. Eur $J$ Biochem 12, 133-142.

Fitch, W. M. (1971). Toward defining the course of evolution: minimum change for a specific tree topology. Syst Zool 20, 406-416.

Hedlund, B. P., Geiselbrecht, A. D., Bair, T. J. \& Staley, J. T. (1999). Polycyclic aromatic hydrocarbon degradation by a new marine bacterium, Neptunomonas naphthovorans gen. nov., sp. nov. Appl Environ Microbiol 65, 251-259.

Huß, V. A. R., Festl, H. \& Schleifer, K. H. (1983). Studies on the spectrophotometric determination of DNA hybridization from renaturation rates. Syst Appl Microbiol 4, 184-192.

Jukes, T. H. \& Cantor, C. R. (1969). Evolution of protein molecules. In Mammalian Protein Metabolism, vol. 3, pp. 21-132. Edited by H. N. Munro. New York: Academic Press.

Lane, D. J. (1991). 16S/23S rRNA sequencing. In Nucleic Acid Techniques in Bacterial Systematics, pp. 115-175. Edited by E. Stackebrandt \& M. Goodfellow. Chichester: Wiley.

Leifson, E. (1963). Determination of carbohydrate metabolism of marine bacteria. J Bacteriol 85, 1183-1184.

Mesbah, M., Premachandran, U. \& Whitman, W. B. (1989). Precise measurement of the $\mathrm{G}+\mathrm{C}$ content of deoxyribonucleic acid by highperformance liquid chromatography. Int J Syst Bacteriol 39, 159-167.

Miyazaki, M., Nogi, Y., Fujiwara, Y., Kawato, M., Kubokawa, K. \& Horikoshi, K. (2008). Neptunomonas japonica sp. nov., an Osedax japonicus symbiont-like bacterium isolated from sediment adjacent to sperm whale carcasses off Kagoshima, Japan. Int J Syst Evol Microbiol 58, 866-871.

Murray, R. G. E., Doetsch, R. N. \& Robinow, F. (1994). Determinative and cytological light microscopy. In Methods for General and Molecular Bacteriology, pp. 21-41. Edited by P. Gerhardt, R. G. E. Murray, W. A. Wood \& N. R. Krieg. Washington, DC: American Society for Microbiology.

Saitou, N. \& Nei, M. (1987). The neighbor-joining method: a new method for reconstructing phylogenetic trees. Mol Biol Evol 4, 406425.

Stackebrandt, E. \& Goebel, B. M. (1994). Taxonomic note: a place for DNA-DNA reassociation and 16S rRNA sequence analysis in the present species definition in bacteriology. Int J Syst Bacteriol 44, 846849.

Tamura, K., Dudley, J., Nei, M. \& Kumar, S. (2007). MEGA4: molecular evolutionary genetics analysis (MEGA) software version 4.0. Mol Biol Evol 24, 1596-1599.

Tindall, B. J. (1990a). A comparative study of the lipid composition of Halobacterium saccharovorum from various sources. Syst Appl Microbiol 13, 128-130.

Tindall, B. J. (1990b). Lipid composition of Halobacterium lacusprofundi. FEMS Microbiol Lett 66, 199-202.

Wayne, L. G., Brenner, D. J., Colwell, R. R., Grimont, P. A. D., Kandler, O., Krichevsky, M. I., Moore, L. H., Moore, W. E. C., Murray, R. G. E. \& other authors (1987). International Committee on Systematic Bacteriology. Report of the ad hoc committee on reconciliation of approaches to bacterial systematics. Int J Syst Bacteriol 37, 463-464. 